\section{崊图 Digital Commons@}

Loyola Marymount University

LMU Loyola Law School

\section{Loyola of Los Angeles} Entertainment Law Review

Volume 19

Number 2 Symposium-The Right of Privacy

Article 5

$1-1-1999$

\title{
An Invasion of Privacy: The Media's Involvement in Law Enforcement Activities
}

Henry H. Rossbacher

Tracy W. Young

Nanci E. Nishimura

Follow this and additional works at: https://digitalcommons.Imu.edu/elr

Part of the Law Commons

\section{Recommended Citation}

Henry H. Rossbacher, Tracy W. Young, and Nanci E. Nishimura, An Invasion of Privacy: The Media's Involvement in Law Enforcement Activities, 19 Loy. L.A. Ent. L. Rev. 313 (1999).

Available at: https://digitalcommons.Imu.edu/elr/vol19/iss2/5

This Symposium is brought to you for free and open access by the Law Reviews at Digital Commons @ Loyola Marymount University and Loyola Law School. It has been accepted for inclusion in Loyola of Los Angeles Entertainment Law Review by an authorized administrator of Digital Commons@Loyola Marymount University and Loyola Law School. For more information, please contact digitalcommons@lmu.edu. 


\section{AN INVASION OF PRIVACY: THE MEDIA'S INVOLVEMENT IN LAW ENFORCEMENT ACTIVITIES}

Henry H. Rossbacher, Tracy W. Young, and Nanci E. Nishimura*

\section{INTRODUCTION}

Thoreau wrote that he "heartily accept[ed] the motto,-' $[t]$ hat government is best which governs least." "l Our forefathers braved treacherous oceans and alien lands emboldened by that belief, after enduring the Crown's heavy hand invading and restricting their religious and personal lives. That is why, among the many freedoms embodied in our Constitution, the right to privacy was included in the Fourth Amendment to protect individuals from arbitrary intrusion by the state. ${ }^{2}$

- An earlier version of this Article was published and copyrighted by the Washington Legal Foundation (No. 80 Critical Legal Issues Working Paper, January 1998). The Foundation has granted permission for this publication.

Henry H. Rossbacher is the principal of Rossbacher \& Associates, a law firm situated in Los Angeles, California, which specializes in civil, criminal and appellate litigation in state and federal court. He has practiced law for over 25 years. Included in his experience are seven years as Assistant United States Attorney and Senior Litigation Counsel for the Department of Justice in Los Angeles and two years as Adjunct Professor of Law at the UCLA School of Law. Mr. Rossbacher is a graduate of the Wharton School of Finance and Commerce of the University of Pennsylvania and of the University of Virginia Law School. He is a Fellow of the Institute of Advanced Legal Studies, London, England. Rossbacher \& Associates litigated the cases of Sanusi, Ayeni and Berger.

Tracy W. Young is a Senior Attorney with Rossbacher \& Associates. She received her B.A. from New York University, cum laude, and her J.D. from Cardozo School of Law in New York.

Nanci E. Nishimura is a Senior Attomey with Rossbacher \& Associates. She received her B.A. and M.A. from the University of Southern Califormia and her J.D. from The Columbus School of Law at The Catholic University, Washington, D.C.

1. Henry David Thoreau, Walden and Civil Disobedience 224 (Owen Thomas ed., W. W. Norton \& Co. Inc. 1966) (1849).

2. The Fourth Amendment to the United States Constitution provides that:

The right of the people to be secure in their persons, houses, papers, and effects, against unreasonable searches and seizures, shall not be violated, and no Warrants shall issue, but upon probable cause, supported by Oath or affirmation, and particularly describing the place to be searched, and the persons or things to be seized.

U.S. CONST. amend. IV. 
This right has been fundamental to the establishment of a more tolerant society devoted to the principles of liberty and justice for all.

As the United States Supreme Court has repeatedly emphasized, the principal objective of the Fourth Amendment is to restrain government incursions into the private lives of individual citizens. ${ }^{3}$ The Warrant Clause of the Fourth Amendment adds a further protection by interposing a detached and neutral judicial officer with the authority to assess the weight and credibility of information provided by investigating law enforcement officers, thereby restraining their otherwise unbridled discretion. ${ }^{4}$

The protection of privacy guaranteed both by the Fourth Amendment and interpretive case law is now threatened by the promise of the media to provide government officials with substantial publicity, combined with the public's voracious appetite for "reality-based" police shows. ${ }^{5}$ Two Federal Circuit Courts of Appeals, the Second and the Ninth, have recently taken affirmative steps to curtail the insidious practice of law enforcement officers entering the private property of individuals under investigation with television cameras in tow. In Ayeni v. Mottola ${ }^{6}$ and Berger $v$. Hanlon, ${ }^{7}$ both courts held that a search of private property videotaped by

3. See Soldal v. Cook County, 506 U.S. 56, 64 (1992); Winston v. Lee, 470 U.S. 753, 758 (1985); INS v. Delgado, 466 U.S. 210, 215 (1984); Delaware v. Prouse, 440 U.S. 648, 653-54 (1979); Warden v. Hayden, 387 U.S. 294, 301 (1967); Jones v. United States, 357 U.S. 493, 498 (1958).

4. See Wong Sun v. United States, 371 U.S. 471, 479 (1963).

5. See Elsa Y. Ransom, Home: No Place for "Law Enforcement Theatricals"--The Outlawing of Police/Media Home Invasions in Ayeni v. Mottola, 16 LOY. L.A. ENT. L.J. 325 (1996) (citing David Tobenkin, Stations Face New Reality: Syndicators Have Host of Offerings, Including Magazine, Health, Law Enforcement Entries, BROADCASTING \& CABLE, Jan. 23, 1995 at 58).

Scenes of law enforcement officers entering the homes of suspects have long been a fixture in television news. In recent years, with the advent of reality-based police shows [i.e., COPS (Fox)], such scenes have become more revealing as the camera began to follow the police inside to give the viewer a close-up look at the search and arrest. At the 1995 meeting of the National Association of Television Program Executives, fifteen new reality-based entertainment programs were unveiled, including at least three that were exclusively devoted to fighting crime.

Id. Reality-based programs are among the most profitable on the air. The minimal costs, plus their popularity domestically and in syndication abroad, gives an overwhelming economic incentive for their production. See Lon Grahnke, $A B C$ Replaces Dramas with "Reality" Gawk Shows, CHICAGo Sun TIMES, May 1, 1997, at 43; Steve Brennan, Reality of U.S. Finds Favor at L.A. Screenings, HollywOOD REP., June 2, 1997, at 1 .

6. 35 F.3d 680 (2d Cir. 1994), cert. denied, 514 U.S. 1062 (1995) (affirming the district court's decision upholding liability against a federal agent). The district court found CBS, its employees and the federal agent had no immunity for their wrongful actions. Ayeni v. CBS, Inc., 848 F. Supp. 362 (E.D.N.Y. 1994), aff'd sub nom. Ayeni v. Mottola 35 F.3d 680 (2d Cir. 1994). The Ayeni appeal resolved an interlocutory issue of qualified immunity. Ayeni, 35 F.3d at 680 .

7. 129 F.3d 505 (9th Cir. 1997) (resolving two separate appeals from the dismissal of two complaints for violation of the Fourth Amendment and related state claims against government 
commercial television cameras was unconstitutional, and that the federal officers involved were not protected by qualified immunity from suit or liability. ${ }^{8}$ The Berger court further held that media participants may be in violation of constitutional rights for acting "under color of federal law." The authors of this Article served as co-lead counsel in both of the Ayeni and Berger cases. ${ }^{10}$

Fourth Amendment jurisprudence has traditionally focused on reasonableness, and whether the action at issue is in furtherance of a legitimate law enforcement purpose. ${ }^{11}$ The actions of the federal officers in the Ayeni and Berger cases were not motivated by law enforcement goals. ${ }^{12}$ Instead, their actions were undertaken to create television entertainment and were therefore patently unreasonable. ${ }^{13}$ As noted by the Second Circuit, "[a] private home is not a sound stage for law enforcement theatricals."

Parts II and III of this Article focus on these pivotal decisions and the strong historical underpinnings upon which these holdings are based as well as the very real problems that collaboration between the press and the police pose to individual privacy. Part IV will then explore the en banc Fourth Circuit decision in Wilson v. Layne ${ }^{15}$ which refused to decide the Fourth Amendment issues resolved in Ayeni and Berger, but nonetheless

agents, media entities and media employees involved in the search). The Ninth Circuit denied petitions for rehearing and suggestions for rehearing en banc filed by the media and government agents on February 25, 1998. Id The United States Supreme Court granted the government agents' Petition for a Writ of Certiorari on November 9, 1998, with argument set for the March 1999 Session. Berger, 129 F.3d at 505, cert. granted, 67 U.S.L.W. 3321 (U.S. Nov. 9, 1998) (No. 97-1927). The Court left the media's petition pending. A conditional cross-petition filed by the Bergers against the media defendants was denied on November 2, 1998. Berger v. Cable News Network, Inc., 129 F.3d 505 (9th Cir. 1997), cert. denied, 67 U.S.L.W. 3299 (U.S. Nov. 2. 1998) (No. 98-38); see infra Part V.

8. Benger, 129 F.3d at 511-12; Ayeni, 35 F.3d at 684-86; see infra Parts II.C, III.

9. Berger, $129 \mathrm{~F} .3 \mathrm{~d}$ at 514 (citations omitted).

10. The Ayeni civil case and the underlying criminal prosecution, United States v. Sanusi, 813 F. Supp. 149 (E.D.N.Y. 1992), were litigated by Rossbacher \& Associates, with Harry C. Batchelder, Jr., Esq. of New York, New York. The Berger civil actions were brought by the Rossbacher firm with Charles "Timer" F. Moses, Esq. and Jay F. Lansing, Esq. of the Moses Law Firm of Billings, Montana, Mr. Berger's counsel in the criminal prosecution.

11. See Graham v. Conner, 490 U.S. 386, 395 (1989); Tennessee v. Garner, 471 U.S. 1, 7-8; Ayeni, 35 F.3d at 686.

12. Berger, 129 F.3d at 511-12; Ayeni, 35 F.3d at 686.

13. See Ayeni, 35 F.3d at 686.

14. Id. District court Judge Jack B. Weinstein made a similar point, "CBS had no greater right than that of a thief to be in the home, to 'capture' the scene of the search on film and to remove the photographic record." Ayeni v. CBS, Inc., 848 F. Supp. at 368.

15. 141 F.3d 111 (4th Cir. 1998) (en banc) (Wilson II), cert. granted, 67 U.S.L.W. 3321 (U.S. Nov. 9, 1998) (No. 98-83). 
shielded federal officers from liability for bringing Washington Post reporters into a private home during an attempted arrest. Part V will discuss the pending United States Supreme Court review of Berger and Wilson.

\section{THE AYENI CASES}

The Ayeni case arose from a search in March 1992 by armed Secret Service Agents of a credit-card fraud suspect's home in Brooklyn, New York. ${ }^{16}$ The agents brought along a CBS camera crew on assignment for the program Street Stories to video and audiotape the search. ${ }^{17}$ Filming of the search was allowed by the agents despite explicit instructions to the contrary from the Assistant United States Attorney in charge of the investigation. ${ }^{18}$

One of the agents wore a wireless microphone and provided a running commentary of the proceedings. ${ }^{19}$ The suspect, Babatunde Ayeni, was not home, but his wife, wearing only a dressing gown, and their five year-old son were present. ${ }^{20}$ Both were visibly shaken by the agents' invasion and the presence of the large video camera. During the search, the CBS camera crew videotaped Mrs. Ayeni and her son repeatedly, despite her objections, and focused close-up shots on the family's personal belongings and documents. ${ }^{21}$ Even though there was no evidence of fraud, the wired agent expressed his belief that Babatunde Ayeni was guilty in an on-camera interview. $^{22}$

\section{A. United States v. Sanusi}

Any discussion of the Ayeni case would be incomplete without reference to the underlying criminal proceeding, United States $v$. Sanusi. ${ }^{23}$ In the criminal case against him Ayeni subpoenaed the videotape of the search from CBS. CBS moved to quash the subpoena on First Amendment and journalistic privilege grounds. ${ }^{24}$ Federal district court Judge Jack B.

16. Ayeni v. CBS, Inc., 848 F. Supp. at 364-65.

17. Id. at 365 .

18. United States v. Sanusi, 813 F. Supp. 149, 161 (E.D.N.Y. 1992).

19. Id. at 152 .

20. Id.

21. Id.

22. Id. The underlying facts are from the Samusi decision by Judge Weinstein, in which he denied CBS, Inc.'s motion to quash a subpoena seeking the unpublished videotape of the search for use in the criminal charges against Babatunde Ayeni. ld. at 161.

23. 813 F. Supp. 149 (E.D.N.Y. 1992).

24. Id. at 151 . 
Weinstein denied the motion and ordered CBS to turn over the tape, which had never been broadcast. ${ }^{25} \mathrm{He}$ reasoned that the tape was material to Ayeni as a "window through which he could demonstrate to the jury . . . the government's zeal to arrest him and its failure to produce any evidence after tearing apart his home." ${ }^{26}$ The court further found the images of a cowering wife and child compelling and likely to influence a jury in Ayeni's favor. ${ }^{27}$ Judge Weinstein was outraged both by the constitutional violations and the fact that the Secret Service had disregarded the direction of the Assistant United States Attorney by allowing a commercial camera crew to accompany the agents on the search. He ordered the United States Attorney to alert the highest authority in the United States Secret Service of this matter and the court's opinion. ${ }^{28}$

The Sanusi opinion analyzed the Fourth Amendment and the right to privacy by discussing early English and United States Supreme Court definitions of the right as protecting "the sanctity of a man's home and the privacies of life." ${ }^{29}$ In statements extremely critical of both the agents and the CBS camera crew, the court cited to the early abuses of the Crown, both through the use of general warrants and the writs of assistance used in the American colonies. ${ }^{30}$

\section{Id.}

26. Id. at $159-60$.

27. Id. at 160.

28. Id. at 161. There is no record that any Secret Service personnel were disciplined as a result of this matter. To the contrary, Department of Justice attorneys flatly denied that the Constitution had been violated. Defendant's Memorandum of Law in Support of Defendant's Motion to Dismiss at 18, Ayeni v. CBS, Inc., 848 F. Supp. 362 (E.D.N.Y. 1944) (No. CV-930957).

29. Samusi, 813 F. Supp. at 157 (quoting Boyd v. United States, 116 U.S. 616, 630 (1886) (interpreting the seminal English case on the subject, Entick v. Carrington \& Three Others, 2 WILS. K.B. 275 (1765), an English trespass action involving an invasion of a home)).

30. Id. at 157-58, 160-61 (citing Steagald v. United States 451 U.S. 204, 220 (1981)). In, Buonocore v. Harris, the Fourth Circuit sets out an extensive discussion of the relationship between the injustices in "the colonies" caused by general warrants and writs of assistance, the Americans' revulsion at their use, and the Founding Fathers' determination that the Constitution prohibited their incorporation into American law. Buonocore v. Harris, 65 F.3d 347, 353-355 (4th Cir. 1995). The United States is not the only former British Colony to find abuses of the right of privacy to be inimical to freedom. Chief Justice McEachern of the Court of Appeal for British Columbia, in a very recent opinion for a unanimous court, suppressed all evidence seized by police during a search pursuant to a search warrant where the Canadian Broadcasting Corporation ("CBC") accompanied authorities into the defendant's home. Regina v. West, No. CA 022220, 1997 CCC LEXIS 1918, at *1 (B.C. Ct. App. Dec. 10, 1997) (citation omitted). $\mathrm{CBC}$ filmed the search, the defendant's arrest, and his home. Id at *2. The opinion emphasizes the universal significance of protecting these rights:

The restraints imposed on government to pry into the lives of the citizen go to the essence of a democratic state. Our private residences are the places where we have the highest possible expectation of privacy against all intrusions except those 
The court, in ordering CBS to produce the unpublished videotape of the search stated:

That CBS both trespassed upon defendant's home and engaged in conduct, with the connivance of the government, directly contrary to Fourth Amendment principles, however, bears upon the court's evaluation of CBS's newsgathering privilege. The First Amendment is a shield, not a sword. Even a reporter must accept limits on how far upon another person's privacy he or she may intrude. ${ }^{31}$

Ayeni agreed to a deal with the government by pleading guilty to attempted credit card fraud. He was fined and sentenced to probation. ${ }^{32}$ The government's case had been irreparably weakened by the Secret Service's conduct which violated the Ayenis' constitutional rights. ${ }^{33}$ This

authorized by law. The importance of all this is demonstrated when one thinks for a moment of the affront to democracy and decency if, as is sometimes the case, a search warrant is issued against an innocent person and a search of his or her residence is conducted with media coverage such as occurred in this case.

Id. at $* 15$ (citation omitted).

31. Sanusi, 813 F. Supp. at 160.

32. Mr. Ayeni had been indicted for conspiring to commit and committing credit card fraud in violation of 18 U.S.C. $\$ \S 1029(\mathrm{a})(3)$, (c)(1); see Sanusi, 813 F. Supp. at 151 .

33. See id at 160-61. The Secret Service had deliberately violated the Ayenis' rights with full knowledge that their conduct might eventually result in a dismissal of the prosecution for unconstitutional conduct. Set forth below is a portion of the deposition of Special Agent Betty Conkling, press assistant to Special Agent-in-Charge (SAC) Heavey of the New York Resident Agency of the Secret Service, testifying as to her conversations with SAC Heavey on the night of the raid, just before taking the CBS camera crew into the Ayeni home:

SA Conkling:A: [T] he policy of the Eastern District [U.S. Attorney]. . was that they would not sanction such activities with the press because of an ongoing investigation....

Rossbacher:Q: What did [SAC] Mr. Heavey say?

A: [T] hat he would be willing to take the risk because the benefit far outweighed the risk.

Q: What was the risk that he was willing to take?

A: I believe we spoke about the possibility of tainting evidence.

June 14, 1995 Deposition Transcript of Betty A. Conkling at 59:1-60:18.

Q: When you and Mr. Heavey were taking the risk, Mr. Heavey was taking the risk of the tainting of the evidence, it would be because the conduct of the Secret Service was illegal; is that right?

A: That the evidence would be tainted.

Q: Because of the illegality of the conduct of the Secret Service?

A: Yes.

Q: You all knew that before you did this?

A: It was discussed, yes.

Id. at 85:20-86:7. It later came to light that the Secret Service took the CBS camera crew into 
conduct resulted in the videotape of the search being admissible at trial as material exculpatory evidence which would likely influence a jury toward acquittal $^{34}$ The government was fortunate that the prosecution was not dismissed.

\section{B. The District Court Decision-Ayeni v. CBS, Inc.}

Mrs. Ayeni and the Ayenis' minor son, Kayode, brought suit against CBS, the CBS Street Stories producer, Meade R. Jorgensen, United States Secret Service Special Agent James Mottola, seven unknown Secret Service Special Agents and two unknown United States Postal Inspectors. ${ }^{35}$ The Ayenis sought civil damages for violation of their Fourth Amendment right to privacy as well as related common law torts, including trespass and infliction of emotional distress. ${ }^{36}$ The damage claim for violation of constitutional rights was brought pursuant to the 1971 United States Supreme Court decision in Bivens v. Six Unknown Federal Narcotics Agents. ${ }^{37}$

Special Agent Mottola, CBS and CBS producer Jorgensen moved to dismiss the complaint under the doctrine of qualified immunity. ${ }^{38}$ They claimed that at the time of the search the Fourth Amendment right to privacy asserted by the plaintiffs was not "clearly established," and that it was "objectively reasonable" for them to believe their acts did not violate the Constitution. ${ }^{39}$ CBS asserted that its acts were protected because they were undertaken with the permission of government agents, and thus assumed the immunity of those agents. ${ }^{40}$

United States district court Judge Weinstein, the same judge who presided over the Sanusi case, disagreed with the plaintiffs' argument. He denied CBS's and Jorgensen's motion on the ground that, as private parties rather than government officials, they were not entitled to government

other homes that day and night and allowed CBS to attend confidential pre-search briefings. Deposition Transcript of Assistant United States Attorney Charles D. Hammerman at 14-17, 5260; Ayeni v. CBS, Inc., 848 F. Supp. 362 (E.D.N.Y. 1994) (No. CV-93-0957).

34. Sanusi, 813 F. Supp. at $159-61$.

35. See Ayeni v. CBS, Inc., 848 F. Supp. 362 (E.D.N.Y. 1994).

36. Id.

37. 403 U.S. 388 (1971) (holding that a federal cause of action may be maintained against federal agents who violate the plaintiff's Fourth Amendment rights).

38. "The doctrine of qualified immunity shields public officials . . from damages actions unless their conduct was unreasonable in light of clearly established law." Elder v. Halloway, 510 U.S. 510,512 (1994); see Anderson v. Creighton, 483 U.S. 635 (1987); Harlow v. Fitzgerald, 457 U.S. 800, 818-19 (1982); see also Soares v. Connecticut, 8 F.3d 917, 920 (2d Cir. 1993).

39. Ayeni v. CBS, Inc., 848 F. Supp. at 365.

40. Id. at 367 
immunity because they were in fact acting merely as "agents" of the government. $^{41}$ Judge Weinstein denied Mottola's motion on the ground that "well established Fourth Amendment principles" prohibit government agents from allowing "a private citizen into a home ... to photograph for non-governmental purposes during the execution of a search warrant .... . ${ }^{\$ 2}$ The fact that no prior case law supported this holding was deemed immaterial by the court, "[r]ather, '[i]t suffices that the [agent] be aware of general well-developed legal principles. $", 43$

The district court drew several legal principles from the Fourth Amendment and the Supreme Court's application thereof, ${ }^{44}$ as well as from federal statutory authority. ${ }^{45}$ First, the court found that the Fourth Amendment guarantees protection against unreasonable governmental intrusions into areas where citizens have a reasonable expectation of privacy, particularly in the home. ${ }^{46}$ Second, the Fourth Amendment ensures that when the government does enter private property, the interruption of privacy is to be minimal and that the search is closely tailored to the purpose of the warrant. ${ }^{47}$ Finally, the district court stated that the Fourth Amendment precludes private parties from searching and seizing private property unless they are officially aiding the government in the execution of the warrant. ${ }^{48}$

Judge Weinstein held that:

Agent Mottola's act of facilitating the CBS camera crew's entry into the apartment and its filming of the search ... was so far from then well established acceptable constitutional behavior that no case law precedent was needed to alert him to the fact that the execution of a warrant for the benefit of private persons violated the Constitution. ${ }^{49}$

41. Id. (citing Wyatt v. Cole, 504 U.S. 158, 167-68(1992)).

42. Id. at $366-68$.

43. Id. at 367 (alteration in original) (citing Jefferson v. Ysleta Indep. Sch. Dist., 817 F.2d 303, 305 (5th Cir. 1987)).

44. Id. at 366.

45. See 18 U.S.C. $\S 3105$ (1994) (providing that a person not specifically authorized to execute a search warrant may not participate in a search unless in aid of the officer authorized by the warrant); Ayeni v. CBS, Inc., 848 F. Supp. at 367.

46. The pivotal case relied on by the court for this proposition was Katz v. United States. 389 U.S. 347 (1967).

47. See Ayeni v. CBS, Inc., 848 F. Supp. at 366 (citing Marron v. U.S., 275 U.S. 192, 195 (1927); Dale v. Bartels, 732 F.2d 278, 284-85 (2d Cir. 1984)).

48. Id. at 368 .

49. Id. 
The court compared Mottola's acts to those of "a rogue policeman using his official position to break into a home in order to steal objects for his own profit or that of another."s0 The district court also considered CBS's videotaping to be an unconstitutional seizure of private images. ${ }^{51}$

\section{The Second Circuit Decision-Ayeni v. Mottola}

Following Judge Weinstein's decision, Mottola appealed to the Second Circuit Court of Appeals. ${ }^{\text {52 }}$ CBS and Jorgensen did not participate in the appeal after reaching a confidential settlement with the Ayenis. ${ }^{53}$ The Second Circuit, in a unanimous opinion by Chief Judge Jon 0 . Newman, affirmed Judge Weinstein's decision, reiterated the Fourth Amendment's protection of the sanctity of Americans' homes, and expanded the qualified immunity analysis. ${ }^{54}$ The court held that: (1) the Fourth Amendment prohibited Mottola from bringing the CBS camera crew into the Ayenis' home; (2) the Ayenis had a clearly established right to privacy under the Fourth Amendment to be protected from such actions; and, (3) Mottola could not have reasonably believed his actions were constitutional. ${ }^{55}$

Based on traditional Fourth Amendment principles, the Second Circuit reasoned that:

[L]aw enforcement officers conducting searches under a warrant are limited in their conduct to either (a) actions expressly authorized by the warrant, or (b) such further actions as are impliedly authorized because they are reasonably related to accomplishing the search authorized by the warrant or accomplishing additional legitimate law enforcement objectives[.] ${ }^{56}$

Mottola exceeded "well-established principles" by bringing into the Ayeni home unauthorized persons not serving any legitimate law enforcement purpose." ${ }^{.57}$

The Ayeni decision did not turn on the identity of the private intruders. Rather, it was based on the intruders' function and whether the

50. Id.

51. Id. at 367-68.

52. Ayeni v. Mottola, 35 F.3d 680 (2d Cir. 1994), cert. denied, 514 U.S. 1062 (1995).

53. Id. at $684 \mathrm{n} .2$.

54. See id at 685-86. The three-member panel deciding the Ayeni interlocutory appeal included Chief Judge Newman, Judge Pierre N. Leval and Judge Lawrence W. Pierce. Id at 680.

55. See id at 686.

56. Id. at 685 (footnote omitted).

57. See id at 686. 
search warrant expressly or impliedly authorized their presence. ${ }^{58}$ The fact that the intruders in Ayeni were the media, although material, was not dispositive, but served to further offend the court and the Constitution. As the Ayeni court stated:

The unreasonableness of [Special Agent] Mottola's conduct in Fourth Amendment terms is heightened by the fact that, not only was it wholly lacking in justification based on the legitimate needs of law enforcement, but it was calculated to inflict injury on the very value that the Fourth Amendment seeks to protectthe right to privacy. The purpose of bringing the CBS camera crew into the Ayenis' home was to permit public broadcast of their private premises and thus to magnify needlessly the impairment of their right of privacy. ${ }^{59}$

The issue of unlawful seizure of private images by videotape and by sound recording, as opposed to the search, was treated separately and concluded in the Ayenis' favor. ${ }^{60}$ The Second Circuit agreed with the District Court that the video and sound recordings qualified as "seizures" under the Fourth Amendment, and rendered the search overly intrusive. ${ }^{61}$ The matter was remanded to the District Court for further proceedings. ${ }^{62}$

\section{THE BERGER CASE}

In Berger v. Hanlon, ${ }^{63}$ the Ninth Circuit Court of Appeals was asked to address a factual scenario similar to that in Ayeni, and to consider issues directly involving the liability of the media under Bivens $v$. Six Unknown Named Agents of Federal Bureau of Narcotics. ${ }^{64}$ Berger involved a written agreement between Cable News Network, Inc. ("CNN") and the federal government. ${ }^{65}$ The agreement allowed CNN to accompany United States Fish and Wildlife Service ("USFWS") agents during their search of a 75,000 acre Montana sheep ranch owned by an elderly couple, Paul and

58. Ayeni v. Mottola, 35 F.3d at 686.

59. Id.

60. Id. at 688-89.

61. Id.

62. See id at 691 . The case came to a conclusion when the authors negotiated a confidential settlement between the government and the Ayenis before trial.

63. 129 F.3d 505 (9th Cir. 1997).

64. See id at 507-08 (discussing whether the media acted sufficiently in concert with federal agents to be held liable as government actors for the agents' violation of the plaintiff's constitutional rights).

65. Id. at 508 . 
Erma Berger. ${ }^{66} \mathrm{CNN}$ and its parent company, Turner Broadcasting Systems, Inc. ("TBS"), "wanted footage of the discovery of evidence showing that Paul Berger was poisoning eagles, and the government wanted the publicity." 67 They planned to broadcast the footage on CNN's and TBS's two cable programs entitled Earth Matters and Network Earth. ${ }^{68}$

On March 11, 1993, shortly before the search, Kris McLean, the Assistant United States Attorney ("AUSA") in charge of the investigation and a defendant in the Bergers' lawsuit, along with CNN producer and correspondent Jack Hamann, executed an agreement on CNN letterhead in which the United States Attorney's Office for the District of Montana agreed to allow CNN to accompany USFWS agents while they executed a search warrant at the Berger ranch. ${ }^{69}$ In return, CNN agreed to embargo any broadcast of the footage until the occurrence of one of the following events: the resolution of the criminal case by plea bargain; instruction of a jury to avoid television; Mr. Berger's waiver of a jury trial; or the government's decision not to bring charges. ${ }^{70}$

In accordance with this agreement, CNN personnel attended and filmed a pre-search briefing. ${ }^{71}$.They were also made privy to confidential information, including the sealed search warrant, in violation of both the Privacy Act and Department of Justice guidelines regulating prosecutors'

66. Id.

67. Id. at 507.

68. Id. at 508.

69. Unless otherwise stated, these facts are based on the recitation included in the Ninth Circuit's opinion. Berger, 129 F.3d at 508-09. The agreement read:

Dear Mr. McLean:

This confirms our agreement that the United States Attorney's Office for the District of Montana agrees to allow CNN to accompany USFWS Agents as they attempt to execute a criminal search warrant near Jordan, Montana, some time during the week of March 22, 1993. Except as provided below, CNN shall have complete editorial control over any footage it shoots; it shall not be obliged to use the footage; and does not waive any rights or privileges it may have with respect to the footage. In return, CNN agrees to embargo the telecast of any videotape of the attempt to execute the search warrant until either: (1) a jury has been impaneled and instructed by a judge not to view television reports about the case; or (2) the defendant waives his right to a jury trial and agrees to have his case tried before a judge; or (3) a judge accepts a plea bargain; or (4) the government decides not to bring charges relating to the attempt to execute the search warrant.

Please acknowledge your agreement to the foregoing by executing the signature line below.

Sincerely, Jack Hamann, Correspondent, CNN, Environmental Unit.

Id. at 508.

70. $I d$.

71. Although the Ninth Circuit has not decided the issue, the Second Circuit held in 1974 that the press must be excluded from pre-search briefings. United States v. Capra, 501 F.2d 267, 279 (2d Cir. 1974), cert. denied, 420 U.S. 990 (1975). 
relations with the media. $^{72}$ The government had earlier obtained sealed search and seizure warrants without disclosing the written agreement or the planned participation of CNN to the issuing Magistrate Judge. ${ }^{73}$

Approximately two weeks later, CNN personnel joined twenty-one armed agents and other law enforcement personnel, including AUSA Mclean disguised as a federal agent, ${ }^{74}$ in a caravan of trucks to converge on the Berger ranch and execute the search warrant. The force was described as "large enough to take on Rambo."75 Paul Berger, at seventyone years of age, had no criminal record, no history of violence, and had only recently been released from the hospital for treatment of emphysema. $^{76}$ Mrs. Berger was eighty-one years old and also of ill health. ${ }^{n}$ Undoubtedly, the onslaught made for good television.

CNN did not just ride along to observe. They mounted video cameras both on the outside and the inside of government vehicles, and documented every action of the federal agents. ${ }^{78}$ CNN also wired USFWS Special Agent Joel Scrafford with a hidden microphone that continuously transmitted live audio exclusively to $\mathrm{CNN}$ technical personnel. ${ }^{79}$ At no time were the Bergers aware of CNN's presence, that the cameras belonged to the media, or that Agent Scrafford was secretly recording them for CNN. ${ }^{80}$ AUSA McLean did not participate in the search, but rather was simply present to be interviewed by $\mathrm{CNN}$ for their upcoming cable program. $^{81}$

72. See Privacy Act 5 U.S.C. $\S 552 a$ (1994); 28 C.F.R. $\S 50.2(b)$ (1998); Department of Justice Manual $\S 1-7.001$, at 1-285 (1990-1991 Supp.); Department of Justice Manual $\S 1-7.000$ (1993 Supp.). The Ninth Circuit denied press access to search-related materials in Times Mirror Co. v. United States, 873 F.2d 1210, 1215-16 (9th Cir. 1989), because disclosure would jeopardize the criminal investigation and pose a grave risk to the targeted individual's privacy.

73. Plaintiffs' First Amended Complaint ๆ 41, Berger v. Hanlon, No. CV 95-46-BLG-JDS (D. Mont. Feb. 26, 1996) (on file with the Loyola of Los Angeles Entertainment Law Joumal) [hereinafter $F A C$ ].

74. Id. at I 55; see Brief of Appellants, Statement of Facts at 4-10, Berger v. Hanlon, 129 F.3d 505 (9th Cir. 1997) (No. 96-35261) (on file with the Loyola of Los Angeles Entertainment Law Joumal).

75. Kevin Helliker, Feathers Fly: CNN Got its Story about Poisoned Eagles But Rancher Cries Foul, WALL ST. J., Sept. 25, 1997, at Al.

76. Id; Brief of Appellants, Statement of Facts at 5, Berger (No. 96-35261).

77. Helliker, supra note 75; see $F A C$, supra note 73, ๆๆ $29,32$.

78. Berger, 129 F.3d at 509.

79. Id.

80. Id.

81. See Brief of Appellants, Statement of Facts at 8, Berger (No. 96-35261). AUSA McLean was disguised as a federal agent wearing an official "raid jacket" emblazoned with "Federal Agent" on the back and a cap with the initials of the Treasury Department's Alcohol, Tobacco and Firearms Bureau. See FAC, supra note 73, ๆ 55. AUSA McLean was neither a Federal Agent nor an employee of the Treasury Department. The candor of the prosecution is 
Agent Scrafford not only recorded outside on the ranch grounds and inside out-buildings, but he also entered the Bergers' home, which was explicitly excluded from the search warrant; the interrogation of $\mathrm{Mr}$. and Mrs. Berger was recorded for CNN. ${ }^{82}$

Agent Scrafford was not content executing the warrant as issued which authorized a search only by federal agents of "The Paul W. Berger Ranch with appurtenant structures, excluding the residence." ${ }^{\text {"W }}$ Rather, Agent Scrafford told Mr. Berger that the district court had ordered the federal agents to search every building on the ranch, never stating that the Berger residence was excluded. Agent Scrafford also informed Mr. Berger that if he did not do as requested, Mr. Berger would be "run ... down to the lockup in Billings."

After ten hours of searching, the agents did not find any evidence of poisoned eagles. ${ }^{85}$ Nonetheless, Mr. Berger was charged with a number of felonies related to the killing of eagles. ${ }^{86}$ The government alleged that he used a pesticide to kill predators, including seventeen eagles, by applying it

typified by the following anecdote from Mr. Helliker's article:

CNN could also have embarrassed Mr. McLean, the prosecutor, by quoting from his closing argument in the criminal trial. To explain to jurors why investigators had refused to let neighbors comfort the elderly Bergers during the 10-hour search, Mr. McLean declared: "Neighbors are not allowed in when you are executing a federal search warrant. My wife wouldn't be allowed in. You don't want anybody else running around." What he hadn't mentioned-and the judge didn't allow jurors to know-was that three CNN employees were his guests.

Helliker, supra note 75 , at Al.

82. Berger, 129 F.3d at 508-09.

83. Id. at 508 (emphasis added).

84. See Brief of Appellants, Statement of Facts at 7, Berger (No. 96-35261). Agent Scrafford's testimony:

Q: And yet you (Scrafford) went with him (Mr. Berger) everywhere he went that day, did you not?

A: Yes, sir.

Q: And at one point did you follow him into the house?

A: Every time he went into the house, yes, sir.

Q: When you talk about going inside the house, I take it you didn't have a search warrant for the interior of the house did you?

A: No, sir, I didn't.

Q: Did you ask Mr. Berger for permission to go inside his house?

A: (No response.)

Q: Did you ask Mr. Berger for permission to go inside his house?

A: No, sir.

Trial Testimony of Agent Scrafford at 115:7-116:4.

85. $F A C$, supra note 73 , ๆ 80.

86. $F A C$, supra note 73, ๆ 79. 
to sheep carcasses. ${ }^{87}$ During the trial, the prosecutors reduced the charge to the killing of "at least one eagle." Eventually, Mr. Berger was acquitted of all charges, except for the misdemeanor charge of using a pesticide contrary to its labeling. ${ }^{89}$

Regardless of the acquittals, in a segment entitled Ring of Death, CNN broadcast the video footage and sound recordings from the search, including recordings made inside the Berger home..$^{90}$ In addition, Correspondent Hamann introduced the segment by implying that $\mathrm{Mr}$. Berger had killed hundreds of eagles. ${ }^{91}$ CNN and TBS broadcast the show at least ten times nationally and internationally. ${ }^{92}$

The Bergers sued AUSA McLean, the federal agents, CNN, TBS, correspondent Jack Hamann, and CNN technical personnel present at the search in two complaints. The complaints, which proceeded on identical courses, sought civil damages for violation of the Fourth Amendment right to privacy under Bivens, violation of the federal wiretapping statute, ${ }^{93}$ and related common law torts, including trespass, infliction of emotional distress and conversion. The Bergers also sought an injunction against any future media broadcasts of the illegally obtained video footage and sound recordings. 94

United States district court Judge Jack D. Shanstrom dismissed the complaints with prejudice, ${ }^{95}$ and the Bergers appealed. ${ }^{96}$ In a lengthy, published, unanimous opinion by circuit court Judge Mary M. Schroeder,

87. Berger, 129 F.3d at 509.

88. Id. at 505.

89. Id.

90. See Helliker, supra note 75.

91. See Brief of Appellants, Statement of Facts at 9, Berger (No. 96-35261).

92. Id. The broadcasts did not reveal Agent Scrafford's misrepresentation of the terms of the warrant or the agent's illegal entry and recording within the Berger residence. The segments, slanted to claim Mr. Berger's acquittals were due to the prejudice of Montana juries rather than the dearth of prosecution evidence, were announced by the USFWS in a special mailing. Special Agent Hanlon used official letterhead to proclaim:

All participants in the Paul Berger ... eagle poisoning investigation, ... the Paul Bergers and non-believers of the world will have a chance to see and hear the truth through the CNN video, not just in Sand Springs, Montana, but the whole WORLD. . Japan, Chile, France, and every place in between.

Id.

93. See Electronic Communications Privacy Act of 1986, 18 U.S.C. $§ 2510-22$ (1994).

94. See Berger v. Hanlon, 129 F.3d 505, 507 (9th Cir. 1997) The United States substituted for AUSA McLean on the trespass claim which was dismissed with prejudice. The Bergers' claim against the United States under the Federal Tort Claims Act is currently pending. Berger v. Hanlon, No. CV-95-46-BLG-JDS, 1996 WL 376364, at *1 (D. Mont. Feb, 26, 1996).

95. Berger, 1996 WL 376364 , at *1.

96. Berger, 129 F.3d at 508. 
joined by circuit court Judge Andrew J. Kleinfeld and district court Judge Rudi M. Brewster, ${ }^{97}$ the Ninth Circuit reversed Judge Shanstrom's decision on all claims except for the wiretapping and conversion allegations, and the request for injunctive relief. This section will focus on the portions of the Berger opinion that relate to the Fourth Amendment claims.

At the outset, the Berger court was not only asked to address the issue raised in Ayeni of whether the Federal Agents were protected from suit and liability under qualified immunity, but it was also asked to decide whether CNN had acted "under color of law," rendering the media liable for constitutional violations under Bivens. ${ }^{98}$ The court's response was clear and emphatic. Videotaping and recording by the media for commercial purposes during a government search on private property is unconstitutional, and neither the press nor the officers involved are protected by qualified immunity. ${ }^{99}$

The Bergers' situation presented a particularly egregious example of the problems posed by concerted action between the media and government. The Berger court considered the extent of their mutual involvement to be material, but did not limit its holding to only extreme cases of joint action. It cited to and approved the Ayeni decision and additionally noted another recent Ninth Circuit decision which also approved Ayeni in recognizing that videotaping searches for non-law enforcement purposes might render the underlying search unreasonable. ${ }^{100}$ The Berger court emphasized the Ayeni court's reliance on federal statutory prohibitions against participation by unauthorized individuals in a search and the needless magnification of the impairment of the right to privacy by publicizing the search. ${ }^{101}$ The court further noted a Fourth Circuit decision denying qualified immunity to a federal officer who brought a private individual on a search of private property because the latter was acting solely for private purposes. ${ }^{102}$

The Berger court distinguished decisions by three other circuits which appear to differ in their approach to this issue, granting either qualified immunity or finding the search reasonable where officers allowed the media to tag along. ${ }^{103}$ In one case decided by the Sixth Circuit, the search

97. Id at 505. District court Judge Rudi M. Brewster was sitting by assignment from the United States District Court for the Southern District of California. Id.

98. Id. at 510-14.

99. See id at 512.

100. Id. (citing Marks v. Clarke, 102 F.3d 1012 (9th Cir. 1996)).

101. Id. at 511 .

102. Berger, 129 F.3d at 511 (citing Buonocore v. Harris, 65 F.3d 347, 356 (4th Cir. 1995)).

103. Id. at 511-12 (citing Wilson v. Layne, 110 F.3d 1071 (4th Cir. 1997), vacated, July 30, 1997 (Wilson I); Stack v. Killian, 96 F.3d 159 (6th Cir. 1996); Parker v. Boyer, 93 F.3d 445 (8th 
warrant authorized photography and videotaping. ${ }^{104}$ This fact alone did not appear dispositive to the Ninth Circuit, which focused on the non-law enforcement purpose of the recording and the active involvement of the media in the planning of the search. The court found the publicity aspect of the media presence in direct conflict with protection of privacy under the Fourth Amendment. ${ }^{105}$

Making explicit what had been implicit in Ayeni $v$. Mottola, ${ }^{106}$ the Berger court addressed the media's liability under Bivens for violating the Bergers' Fourth Amendment rights. ${ }^{107}$ The media, as private parties, could be held liable only if they acted "under color of law." 108 The court employed the "joint action"109 test enunciated by the United States Supreme Court and concluded that 'the 'inextricable' involvement of the media with both the planning and execution of this search, the government's active involvement with the media's news gathering activities, and the mutually-derived benefits, is more than enough to make the media government actors." 110

\section{WILSON V. LAYNE AND THE FOURTH CIRCUTT}

Simultaneous to the Berger case which was winding its way from the district court in Montana through the Ninth Circuit, a similar case, Wilson v. Layne, ${ }^{111}$ was proceeding from the Maryland District Court through the Fourth Circuit. On April 14, 1992, U.S. Marshals took Washington Post reporters and photographers into the Wilsons' private home while

Cir. 1996), cert. denied, 117 S. Ct. 1081 (1997)). The Fourth Circuit in Wilson v. Layne re-heard arguments in the case en banc and issued a new opinion in April 1998, reported at 141 F.3d 111 (4th Cir. 1998) (Wilson II).

104. See Stack v. Killian, 96 F.3d 159 (6th Cir. 1996). The Stack case involved a 1991 search that pre-dated the Sanusi and Ayeni decisions and the Fourth Circuit decision in Buonocore. Id

105. Berger, 129 F.3d at 511.

106. 35 F.3d 680 (2d Cir. 1994). Judge Weinstein found the media liable, as noted above, at the district court level in Ayeni v. CBS, Inc., 848 F. Supp. 362 (E.D.N.Y. 1994).

107. Berger, 129 F.3d. at 514-16.

108. Id. at 514 (citing Johnson v. Knowles, 113 F.3d 1114, 1117 (9th Cir. 1997)).

109. See Dennis v. Sparks, 449 U.S. 24, 27 (1980) (holding that private actors can be considered government actors if they are "willful participant[s] in joint action with the [government] or its agents").

110. Berger, 129 F.3d. at 515 (citations omitted). The media claims in Berger are analyzed together with the pending Food Lion litigation by Professor Randall P. Bezanson in his Article. Randall P. Benzanson, Means and Ends and Food Lion: The Tension Between Exemption and Independence in Newsgathering by the Press, 47 EMORY L.J. 895 (1998).

111. 110 F.3d 1071 (4th Cir. 1997) (Wilson I), rev'd on other grounds, 141 F.3d 111 (4th Cir. 1998) (en banc) (Wilson II), cert. granted, 67 U.S.L.W. 3321 (U.S. Nov. 9, 1998) (No. 9883). 
attempting to effect an arrest. ${ }^{112}$ While there, the press photographed both Mr. and Mrs. Wilson, neither of whom was suspected of crimes or arrested. ${ }^{113}$ In fact, the officers were looking for the Wilsons' son who was not present. ${ }^{114} \mathrm{Mr}$. Wilson was photographed pinned on the floor with a gun to his head, dressed only in his undershorts. ${ }^{115}$ Mrs. Wilson was photographed wearing only a sheer nightgown. ${ }^{16}$ They had been awakened from sleep at 6:45 a.m. to find armed plainclothes officers, accompanied by the reporters, in their living room. ${ }^{117}$

The Wilsons sued the federal and local officers who were present, but not the press, for, inter alia, violating the Fourth Amendment by permitting the media to enter the Wilsons' home to photograph the execution of the arrest warrant. ${ }^{118}$ The officers asserted qualified immunity, claiming that there was no clearly established constitutional right under the Fourth . Amendment prohibiting law enforcement from bringing the press into a private residence during the execution of an arrest warrant. ${ }^{119}$

The district court refused to dismiss the Fourth Amendment claim. The court identified a constitutional issue, finding that the violation of the Fourth Amendment right to privacy was clearly established. ${ }^{120}$ This decision was overturned in a split decision by a three judge panel of the Fourth Circuit. ${ }^{121}$ The majority refused to decide whether a constitutional privacy right was in fact violated, content only with a finding that such a right was not clearly established at the time of the incident. ${ }^{122}$ The majority refused to follow Ayeni and purported to distinguish its own prior decision in Buonocore $v$. Harris, ${ }^{123}$ claiming that because the press only followed

112. Wilson $I, 110$ F.3d at 1077 (Russell, J., dissenting).

113. Id. at 1076.

114. Id. at 1072.

115. Id. at 1076 .

116. Id.

117. Id.

118. Wilson $I I, 141$ F.3d at 113.

119. Wilson $I, 110$ F.3d at 1073.

120. Id.

121. Id. at 1071 .

122. Id. at 1075-76. The majority's failure to confront and decide the constitutional issue as to whether the officer's actions violated the Fourth Amendment before it moved to the issue of immunity is inexplicable. In Siegert v. Gilley, the Supreme Court found that the determination of a violation of a constitutional right is a threshold question that must be assessed before analyzing the validity of a claim of immunity. Siegert v. Gilley, 500 U.S. 226, at 232-33 (1991). The Supreme Court criticized the District of Columbia Court of Appeals for refusing to decide the constitutional issue while going on directly to decide whether the right alleged was clearly established. Id. The Supreme Court clearly stated that in order to reach the merits of the case the constitutional violation must be addressed first. Id.

123. 65 F.3d 347 (4th Cir. 1995). 
the police, no private search occurred. ${ }^{124}$ The dissent, however, pointed out that Buonocore could be read to actually prohibit government agents from allowing the presence of private citizens unrelated to the execution of the search warrant. ${ }^{125}$ The dissent went further finding, in direct accord with Ayeni, that Fourth Amendment jurisprudence had long ago clearly established that police may not invite reporters into private homes unless the warrants expressly or impliedly authorized the press to be there. ${ }^{126}$

Subsequently, the Fourth Circuit granted review en banc. The eleven judges affirmed the prior split decision by a six to five vote. The majority opinion again decided only the qualified immunity issue, refusing to adjudicate the constitutional issue. ${ }^{127}$ The majority did, however, adopt a very confused policy analysis advanced by the police officers' counsel that press coverage serves a legitimate law enforcement purpose. ${ }^{128}$ While refusing to hold that this purpose "actually justified the reporters' presence while the warrant was executed; we merely hold that the absence of clearly established law holding that [the possible law enforcement purposes] were not adequate to warrant [the reporters'] presence, reasonable officers may have believed"129 these purposes to be adequate. Of course, as the dissent pointed out, there was no evidence that the officers believed that. ${ }^{130}$

The dissent undertook a full-scale historical constitutional analysis, commencing with Semayne's Case ${ }^{131}$ in 1604 and sweeping into the present. $^{132}$ The dissent traced the development of Fourth Amendment law, exploded the notion that Buonocore did not prohibit this conduct, ${ }^{133}$ and

124. Id. at 1076 n.5.

125. See id at 1077 (Russell, J., dissenting) (citation omitted).

126. $I d$.

127. Wilson 11,141 F.3d at 118 .

128. Id at 116. For example, the purpose may be served by affording protection to the officers by reducing the possibility that the target of a warrant will resist arrest in the face of recorded evidence of his actions. Additionally, it could be asserted that facilitating accurate reporting that improves public oversight of law enforcement activities is a legitimate law enforcement purpose because it deters crime, as well as improper conduct by law enforcement officers. Id.

129. Id. at $118 \mathrm{n} .11$. "[W]e do not address whether the officers' conduct was constitutional or appropriate ..." Id. at 118; see supra note 122 and accompanying text.

130. Id. at 125-26 (Murnaghan, J., dissenting). The dissent also disagreed with the majority that there was no seizure. Id. at 127-29.

131. Semayne's Case, 5 Co. Rep. 91a, 77 Eng. Rep. 194 (K.B. 1604) (prohibiting the government from forcibly entering a home at the bequest of a private party).

132. Wilson II, 141 F.3d at 121-25 (Murnaghan, J., dissenting).

133. The dissent quoted Buonocore:

In sum, the reporters' observations and photography constituted an additional private search and seizure not described in the warrant nor carrying out its purposes. The officers' inviting the reporters into the home to conduct their search for news while the officers executed the arrest warrant thus falls squarely under 
concluded that "we should wholeheartedly agree" with Ayeni's decision that the officers' conduct was constitutionally unreasonable. ${ }^{134}$ The dissent went on to agree with the Berger decision as well. ${ }^{135}$ The justices equated the agents' conduct in Maryland with that in the Montana and New York cases. ${ }^{136}$ Specifically, the court found the execution of the arrest warrant at the Wilsons' home was similar to the search of the Bergers' ranch in that both searches were intended to serve a major purpose other than law enforcement. ${ }^{137}$ "These invasions, no less than the search of the Ayenis" home, turned private property into a stage for 'law enforcement theatricals." $" 138$

The dissent flatly posed the issues:

The majority goes much too far when it sanctions unconsentedto public tours of private homes, with photography allowed, under the guise of an arrest warrant. After today, any police officer entering a private home under a search or an arrest warrant may bring along any observer as a bystander, even an observer there only to serve his own commercial purposes or to satisfy mere curiosity.... Far from protecting us against

Buonocore, and was clearly prohibited by the Fourth Amendment in $1992 \ldots$. To conclude otherwise would authorize law enforcement officers to invite private individuals to engage in conduct that would constitute trespass were it not conducted under the guise of a search warrant. Neither the Fourth Amendment nor $\S 3105$ grants government agents such authority.

Id. at 129 (quoting Buonocore v. Harris, 65 F.3d 347, 359 (4th Cir. 1995)); see 18 U.S.C. $\$ 3105$ (1994).

134. Wilson II, 141 F.3d at 129-30 (Murnaghan, J., dissenting).

135. Id. at 130-31. The Fourth Circuit minority opinion noted a conflict with the Eighth Circuit's divided decision in Parker v. Boyer, 93 F.3d 445 (8th Cir. 1996), cert. denied, 117 S. Ct. 1081 (1997). The Parker case is confusing as there were no allegations of "state action" by the press or police. The district court held that the plaintiffs had not made allegations of concerted action by the police and that there was no evidence of "any affirmative agreement." Parker $v$. Clark, 905 F. Supp. 638, 642 (E.D. Mo. 1995). The majority opinion seemed to ignore the facts found by the district court and it disagreed with Berger and Ayeni in general. The majority's failure to acknowledge either an agreement or active conduct makes Parker a muddled precedent and, in our view, not a clear conflict with Berger. The Wilson II dissent's point regarding conflict is supported, however, by the Parker dissent's discussion of the actual facts. As the Parker dissent pointed out, the defendant news crew "acted in concert with the police" as "willful participant[s]" insofar as they contacted the police, solicited an invitation to join the police, were invited by a police sergeant, and "came to the location with the police [in the police car] and could not have entered if the police had not done so first." Parker v. Boyer, 93 F.3d at 449 (Rosenbaum, J., dissenting). The police chief even testified that the media's conduct would constitute a trespass if it videotaped a search of a citizen's house without the citizen's permission. Id. at 447. In any case, the effect of Parker was mainly relevant to the Supreme Court's criteria for certiorari review, now a decided issue.

136. Wilson II, 141 F.3d at 129-31 (Murnaghan, J., dissenting).

137. Id. (citations omitted).

138. Id. 
tyrannical police practices, the majority's opinion today threatens one of the most sacred rights protected by the United States Constitution. From now on in the Fourth Circuit, unlike the Second or Ninth, if ever the government need enter a private home, the home-and its occupants-can be laid bare for all the world to see.

The Fourth Amendment guarantees that the sanctity of the home, one's castle, will not be disturbed unless by warrant or pursuant to a specific warrant exception. These reporters were not mentioned in the warrant. Their presence was not justified by any exception to the warrant clause, nor was it reasonably necessary to accomplish the purposes of the warrant. These reporters were in the Wilsons' home strictly for their own commercial news-gathering purposes. When police orchestrate the entry of third parties, including newspaper reporters, into a private home without the consent of the homeowner, without the authorization of a warrant, for no legitimate law enforcement need and justified by no exigent circumstances, they violate the clearly established protections of the Fourth Amendment. ${ }^{139}$

Of course, this opinion was merely posited by the dissent. The majority refused to respond to the dissent, preferring apparently to perpetuate these police practices by preventing a clear resolution of the conduct's propriety. ${ }^{140}$

\section{THE UNITED STATES SUPREME COURT}

Following denial of rehearing, both the federal agents and the media defendants petitioned the Supreme Court for review in Berger. Simultaneously, the Wilsons asked for review of the decision in their case as well.

139. Id. at 132 .

140. The Supreme Court decision in Siegert requires resolution of whether there has been a constitutional violation as "a threshold issue." Siegert v. Gilley, 500 U.S. 226, 232-33 (1991). Subsequent to the Fourth Circuit's decision, the Supreme Court in County of Sacramento v. Lewis, 118 S.Ct. 1708 (1998), relying directly upon Siegert stated:

[A]s we have held, the better approach to resolving cases in which the defense of qualified immunity is raised is to determine first whether the plaintiff has alleged a deprivation of a constitutional right at all. Normally, it is only then that a court should ask whether the right allegedly implicated was clearly established at the time of the events in question ..... [I]f the policy of avoidance were always followed in favor of ruling on qualified immunity whenever there was no clearly settled constitutional rule of primary conduct, standards of official conduct would tend to remain uncertain, to the detriment both of officials and individuals.

Id. at 1714 n.5. 
Both cases reached the Supreme Court and, it is now known, will be decided together. ${ }^{141}$ On November 9, 1998, the Supreme Court granted certiorari to decide the following questions: " 1 . Whether law enforcement officers violate the Fourth Amendment by allowing members of the news media to accompany them and to observe and record their execution of a warrant? 2. Whether, if this action violates the Fourth Amendment, the officers [are] nonetheless entitled to defense of qualified immunity." 142

The Court, however, only granted review to the federal agents in Berger. The petition by the media has been denied. ${ }^{143}$ Thus, the press will not participate as parties in the argument.

\section{CONCLUSION}

The Ayeni and Berger courts were troubled by the reality of the government and the press marching hand-in-hand with the common goal of achieving higher ratings, as were the dissenting judges in Wilson. In light of the traditional roles played by each, where the media generally serves as a government watchdog and the government seeks to govern without unduly interfering with individual liberties, the media and government make strange bedfellows. The corrupting influence of their joining forces to create titillating television shows has blurred roles, with government agents becoming reporters and reporters becoming government agents. The negative effects of this insidious arrangement, the weakening of both the media and the government, are exemplified by the Berger, Ayeni and Wilson cases.

In Ayeni, the media's involvement in the pre-indictment search weakened the prosecution's case, resulting in an impaired prosecution. An innocent woman and child were cynically subjected to indecent indignities solely for commercial purposes. In effect, the government considered good press more important than admissible evidence or constitutional rights.

In Berger, CNN executed an agreement giving the government control over when the network could publish the video of the search. ${ }^{144}$ The oft-made media argument that their presence at a search could serve to

141. Wilson II, 141 F.3d 111 (4th Cir. 1998) (en banc), cert. granted, 67 U.S.L.W. 3321 (U.S. Nov. 9, 1998) (No. 98-83); Berger v. Hanlon, 129 F.3d 505 (9th Cir. 1997), cert. granted, 67 U.S.L.W. 3321 (U.S. Nov. 9, 1998) (No. 97-1927).

142. Id.

143. Berger v. Cable News Network, Inc., 129 F.3d 505 (9th Cir. 1997), cert. denied, 67 U.S.L.W. 3299 (U.S. Nov. 2, 1998) (No. 98-83).

144. Mr. Helliker's 1997 article in the Wall Street Joumal observed that "[t]he allure of access often tempts the media into deals that give the authorities substantial power to shape both the content and timing of stories." See Helliker, supra note 75. 
document police abuses was shown to be disingenuous. If the agents had beaten the elderly Bergers, CNN would not have been able to immediately report that fact. The press suppressed its knowledge of police misconduct. The press sold its independence to the police, and the police sold its public trust to the press. ${ }^{145}$

In Wilson, not one federal agent restrained the press in its seizure of images of two virtually unclothed citizens in their own home who were not even the objects of the arrest warrant. Indeed, the raid was only one of a series in which the Washington Post repeatedly entered private homes at police invitation, publishing photographs of the presumed innocent.

In these three cases, law enforcement personnel were likely distracted from their work by the media presence. The agents were required to perform for the cameras and to "baby-sit" their lay charges, tagging along on a police function. ${ }^{146}$ The written agreement between the government

145. Max Frankel, a preeminent journalist and the former Executive Editor of the New York Times, has found the government's and journalists' conduct in Berger "collusive" and reprehensible, condemning the Turner and Time Warner First Amendment claim. He claims:

They contend that they have a right to barge into your home with the cops and to broadcast whatever happens, whether or not the police behave legally or have proved you guilty of a crime.

Most uncollegially, I am pleased to report that the media are losing this case. They had better gird themselves for a time when they will have to entertain the world without the razzle-dazzle execution of a search warrant. When this legal battle is finally exhausted, the cameras and cops may also have to curb other collusive ways they prey upon the unsuspecting. At the least, they may be required to read citizens something like their "Ted Turner rights"- "You are in range of a hidden camera and have the right to demand that the TV guys reveal themselves and get out of your house."

I propose enshrining Turner alongside Miranda because his CNN and Turner Broadcasting System, both now merged into Time Warner, took the media's shameless claim to a right of trespass to a preposterous extreme.

Max Frankel, $A$ Case of Sheep v. Coyotes-When the Police and News Crews Collude, They Prey on the Unsuspecting, N.Y. TIMES MAG. at 30 (Dec. 21, 1997).

146. The execution of search and arrest warrants on private property can often be dangerous work, entailing as it does the invasion of private homes and apartments where armed suspects are often unwilling to peaceably comply with law enforcement demands. A reporter or camera crew technician can easily be shot or harmed in some way during one of these "news gathering" excursions, a likely scenario that raises unnecessary questions, and risks, of responsibility and liability. It is wrong for law enforcement agencies to endanger their personnel by requiring that they perform guard or guide duties for untrained civilians while they perform the often dangerous and always stressful job of executing warrants in criminal cases. These duties are also inherently demeaning to law enforcement personnel.

The majority in Wilson II discusses with an apparent straight face the proposition that press presence on police searches might serve a "law enforcement purpose" by protecting officers, presumably using the press as shields. "For example, the purpose may be served by affording protection to the officers by reducing the possibility that the target of a warrant will resist arrest in the face of recorded evidence of his actions." Wilson II, 141 F.3d at 116 . One hopes in vain that this discussion is facetious. Armed criminals willing to shoot it out with armed cops will not be deterred by unarmed civilians poking cameras at them while the bullets fly. Well-meaning 
and CNN in Berger mirrors the tacit, implicit, and unavoidable arrangements between the media and the government whenever the media relies on the government for access to stories, and the government violates the limits on its police powers to benefit itself by aligning with the media. In this co-dependent relationship, the media subordinates its independence and the government performs for the cameras. The result is prosecutions motivated by publicity, not the public interest. The losers are the citizens of this country and their constitutional rights.

The constitutional right of privacy is fundamental to the American conception of liberty. The right to be let alone, free from venal intrusions by the media and government, has been self-evident since the American Revolution. The holdings of Ayeni and Berger, and the minority opinion in Wilson, uphold and protect these basic freedoms. The majority in Wilson forfeits those freedoms, failing even to dignify them with a decision on the merits. The Supreme Court will now decide. ${ }^{147}$

federal agents who are supposed to be professionally trained in self-preservation and protection may well endanger themselves by attempting to protect untrained, unarmed, and unarmored amateurs whose actions in a shoot-out are unpredictable. It also does not appear to have occurred to the court that cops can carry cameras too.

147. The issues are joined, even if the parties seem to be like Eliot's women:

In the room the women come and go

Talking of Michelangelo.

T.S. Eliot, The Love Song of J. Alfred Prufrock (1917). 
